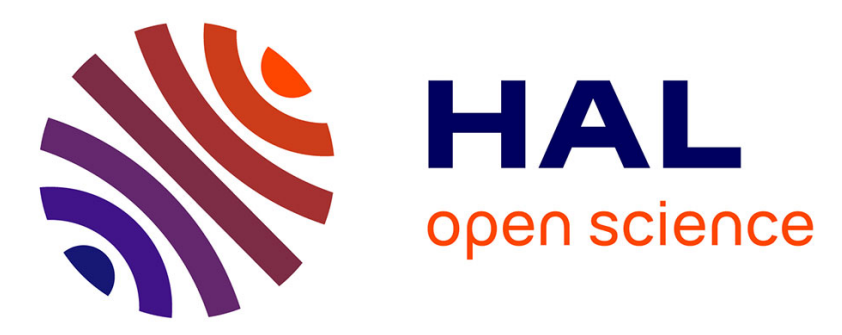

\title{
CRITICAL SURVEY: The Third Sector and the Regional Development of Social Capital
}

\author{
Kean Birch, Geoff Whittam
}

\section{To cite this version:}

Kean Birch, Geoff Whittam. CRITICAL SURVEY: The Third Sector and the Regional Development of Social Capital. Regional Studies, 2008, 42 (03), pp.437-450. 10.1080/00343400701874222 . hal00514709

\author{
HAL Id: hal-00514709 \\ https://hal.science/hal-00514709
}

Submitted on 3 Sep 2010

HAL is a multi-disciplinary open access archive for the deposit and dissemination of scientific research documents, whether they are published or not. The documents may come from teaching and research institutions in France or abroad, or from public or private research centers.
L'archive ouverte pluridisciplinaire HAL, est destinée au dépôt et à la diffusion de documents scientifiques de niveau recherche, publiés ou non, émanant des établissements d'enseignement et de recherche français ou étrangers, des laboratoires publics ou privés. 


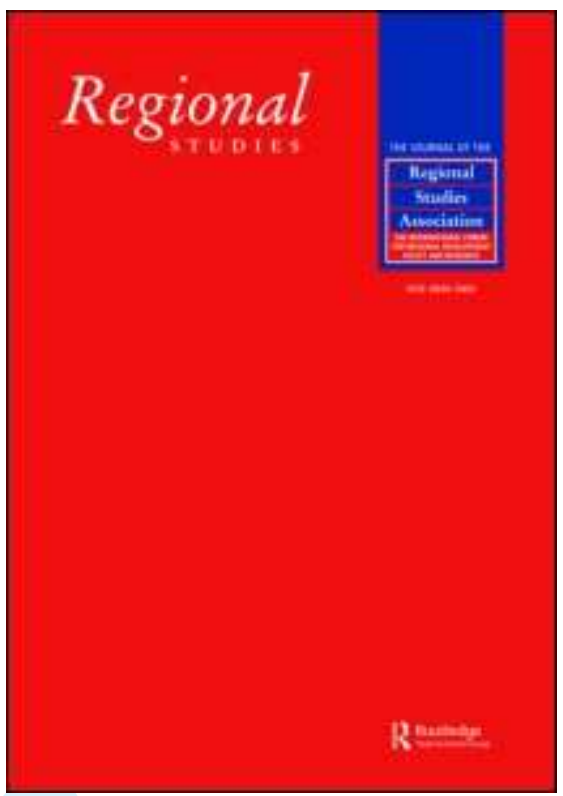

\section{CRITICAL SURVEY: The Third Sector and the Regional Development of Social Capital}

\begin{tabular}{|r|l|}
\hline Journal: & Regional Studies \\
\hline Manuscript ID: & CRES-2006-0246.R2 \\
\hline Manuscript Type: & Critical Surveys \\
\hline JEL codes: & $\begin{array}{l}\text { L3 - Nonprofit Organizations and Public Enterprise < L - Industrial } \\
\text { Economics, R58 - Regional Development Policy < R5 - Regional } \\
\text { Government Analysis < R - Urban, Rural, and Regional Economics }\end{array}$ \\
\hline Keywords: & $\begin{array}{l}\text { Third Sector, Social economy, Social enterprise, Social } \\
\text { entrepreneurship, Social Capital, Regional development }\end{array}$ \\
\hline
\end{tabular}

\section{SCHOLARONE Manuscripts}




\title{
CRITICAL SURVEY: The Third Sector and the Regional Development of Social \\ Capital
}

\author{
KEAN BIRCH \\ Centre for Public Policy for Regions \\ University of Glasgow \\ Ivy Lodge \\ 63 Gibson Street \\ Glasgow \\ G12 8LR
}

Tel: $00+44(0) 1413301913$

Email: kean.birch@socsci.gla.ac.uk

\section{GEOFF WHITTAM}

Paisley Business School

University of Paisley

Paisley

PA1 2BE

Tel: 00 +44 (0)141 8483368

Email: Geoff.Whittam@paisley.ac.uk 
First received: October 2006

Accepted: August 2007 


\begin{abstract}
There is a growing academic and policy interest in the Third Sector and its potential impact on regional development. A key aspect of the Third Sector is its role in regional development through the promotion of social capital. However, there is considerable debate around the definition of the Third Sector that limits our understanding of its impact. Here we first disentangle a number of ambiguities to clarify the distinctions between the concepts before secondly exploring the relationship between the regional development of social capital and the various aspects of the Third Sector. Finally we consider UK policy agendas and initiatives in light of the earlier discussion.
\end{abstract}

KEY WORDS: Third Sector, social economy, social enterprise, social entrepreneurship, social capital, regional development.

JEL CODES: L3; R0; R58; R5

\title{
$\underline{\text { Le secteur tertiaire et le développement régional du capital social }}$
}

\section{$\underline{\text { KEAN BIRCH et GEOFF WHITTAM }}$}

\section{RESUME}

Le monde universitaire et la politique s'intéressent de plus en plus au secteur tertiaire et à son impact potentiel sur le développement régional. Un aspect majeur du secteur tertiaire est son rôle dans le développement régional par la promotion du capital social. Le secteur tertiaire reste toutefois l'objet d'un débat considérable qui limite notre compréhension de 
son impact. Dans cet article, nous commençons par démêler un certain nombre d'ambiguïtés pour préciser la distinction entre les concepts avant, dans un deuxième temps, d'explorer les relations entre le développement régional du capital social et les divers aspects du secteur tertiaire. Enfin, nous analysons les programmes et les initiatives de la politique du Royaume-Uni à la lumière des précédentes discussions.

Mots-clés : secteur tertiaire, économie sociale, entreprise sociale, entreprenariat social, capital social, développement régional.

CODES JEL : L3; R0; R58; R5

\title{
Der Dritte Sektor und die Regionalentwicklung von Sozialkapital KEAN BIRCH and GEOFF WHITTAM
}

\author{
ABSTRACT \\ Wissenschaft und Politik interessieren sich zunehmend für den Dritten Sektor \\ und seine potenzielle Auswirkung auf die Regionalentwicklung. Ein zentraler \\ Aspekt des Dritten Sektors ist seine Rolle in der Regionalentwicklung durch die \\ Förderung von Sozialkapital. Allerdings gibt es eine beträchtliche Debatte \\ hinsichtlich der Definition des Dritten Sektors, wodurch unser Verständnis seiner \\ Auswirkung eingeschränkt wird. In diesem Beitrag beseitigen wir zunächst \\ verschiedene Unklarheiten, um die Unterschiede zwischen den Konzepten zu \\ erläutern. Anschließend untersuchen wir die Beziehung zwischen der \\ Regionalentwicklung des Sozialkapitals und den verschiedenen Aspekten des \\ Dritten Sektors. Zuletzt erörtern wir die politischen Agenden und Initiativen in \\ Großbritannien im Hinblick auf die frühere Diskussion. \\ KEY WORDS: \\ Dritter Sektor \\ Sozialwirtschaft \\ Sozialunternehmen \\ Soziales Unternehmertum \\ Sozialkapital \\ Regionalentwicklung
}


JEL CODES: L3; R0; R58; R5

El Tercer Sector y el desarrollo regional del capital social KEAN BIRCH and GEOFF WHITTAM

\begin{abstract}
Existe un creciente interés académico y político en el Tercer Sector y su posible efecto en el desarrollo regional. Un aspecto fundamental del Tercer Sector es la función que desempeña en el desarrollo regional mediante el fomento del capital social. Sin embargo, existe un debate significativo acerca de la definición del Tercer Sector que limita nuestra capacidad para entender sus repercusiones. Por ende aquí esclarecemos una serie de ambigüedades para clarificar las diferencias entre los conceptos antes de explorar la relación entre el desarrollo regional del capital social y los diferentes aspectos del Tercer Sector. Concluimos con un análisis del programa y las iniciativas políticas en el Reino Unido con respecto a la discusión anterior.
\end{abstract}

KEY WORDS:

Tercer Sector

Economía social

Empresa social

Empresariado social

Capital social

Desarrollo regional

JEL CODES: L3; R0; R58; R5 


\section{INTRODUCTION}

Despite the importance of the Third Sector to the UK and its regions (see SMALLBONE, et al. 2001; ECOTEC, 2003; McGREGOR et al., 2003; ARTHUR et al., 2004; HUDSON, 2005; IFF RESEARCH, 2005), there is considerable confusion over its definition, the distinction between its constituent parts, and its impact on regional development (ADAMS et al., 2003; HARDING and COWLING, 2004). In part the existence of numerous terms like social economy, social enterprise and social entrepreneurship produces considerable confusion because these concepts have only been subject to academic attention and debate in the last decade or so (SEELOS and MAIR, 2005). Thus it is particularly important for a journal like Regional Studies to address the issue of socio-economic development that such debates on the Third Sector have stimulated, especially in relation to the increasing importance placed on social embeddedness and social capital in regional development.

At present the lack of clarity in discussions around the Third Sector leads to frequent theoretical and empirical slippage between concepts and terms such as the social economy, social enterprise and social entrepreneurship. As a result, HAUGH (2005b, p.10) argues that "research in social entrepreneurship ... is hindered by the lack of standard and universally acceptable definitions". This is something that NICHOLLS (2006) suggests is particularly important to solve considering that the Third Sector has become so popular with academics and policy-makers, although others would disagree with the aim of creating such 'essentialist' typologies (see MOULAERT and NUSSBAUMER, 2005). Section 2 of this article therefore explores three core concepts in the Third Sector - the social economy, social enterprise and social entrepreneurship - to 
draw out the differences between organisational and institutional characteristics, different activities and their motivation. In so doing we address the relationship between the concepts and what implications these might have for the Third Sector as a whole in order to contribute to ongoing debates that cut across the social sciences. However, in so doing we do not seek to eliminate conceptual diversity altogether.

Arguably the growing interest in the Third Sector can be seen as a result of the 'hollowing out' of the state provision of services and goods for their citizens (BUDD, 2003; PATON, 2003; FYFE, 2005) as well as recent policy concern with sustainable development, climate change and other ecological issues. For example, the current British government's social enterprise policy has been oriented around the promotion of social enterprises as a "diverse and enterprising way of tackling social and environmental issues" (SMALL BUSINESS SERVICE, 2005) including social inclusion, local regeneration and community empowerment (see DTI, 2002). Part of the policy interest is derived from the perceived relationship between the regeneration of deprived and disadvantaged communities and social capital (HM TREASURY, 1999; DEVINEWRIGHT et al., 2001), which we discuss in detail in Section 3. Thus it has been argued that social capital can be promoted through the Third Sector (LEADBEATER, 1997; THOMPSON et al., 2000; see FYFE, 2005 for critical view), which, in turn, promotes and cements (sustainable) regional development (DEVINE-WRIGHT et al., 2001; RYDIN and HOLMAN, 2004).

In the final section of the article we turn to regional policy to illustrate how the relationship between regional development and the Third Sector has been conceived in rather limited terms by both national and 'regional' governments. We focus explicitly on 
the UK because of the strong recent interest in social enterprise in academic and policy debates. We have also chosen to focus on Scotland because it represents an example of a 'region' suffering from the consequences of long-term socio-economic uneven development that has adopted Third Sector policies distinct from the national and other devolved governments. This discussion illustrates the differences between policy agendas and initiatives at different scales and how they impact on the regional development of social capital within and across different geographical locations. In particular we separate discursive claims from policy implementation in order to consider the conceptual confusion around visions of and for the Third Sector that blur the already confused distinction between the social economy, social enterprise and social entrepreneurship (see ARTHUR et al., 2003). Thus we highlight the current government emphasis on public service delivery in Third Sector policy, especially in relation to regional development, and how this might prove detrimental to the promotion of social capital.

\section{THREE CORE CONCEPTS: SOCIAL ECONOMY, SOCIAL ENTEPRISE AND SOCIAL ENTREPRENEURSHIP}

The literature on the Third Sector, particularly the recent expansion of interest in social enterprise and social entrepreneurship, emphasises the importance of the "triple bottom line' of economic, social and ecological goals (BOSCHEE and McCLURG, 2003; SOCIAL ENTERPRISE COALITION, 2003; ELKINGTON, 2004; WALLACE, 2005; JONES and KEOGH, 2006). ${ }^{\mathrm{i}}$ However, there is considerable blurring between concepts like the social economy, social enterprise and social entrepreneurship as well as between 
the market, state and Third sector. Thus although the organisational, institutional and motivational characteristics of the Third Sector sets it apart from the private and state sectors, it does not mean that there is no link between these three sectors.

For example, the 'hollowing out' of the state and retreat from the state provision of welfare has meant that social enterprise is being used to deliver government agendas and policies (PATON, 2003), whilst the social objective precludes a market-based solution. In turn, social entrepreneurs or entrepreneurship can emerge in and operate across both the state and market sectors where service delivery may depend on individually motivated people or where the development of the quasi-philanthropy of corporate social responsibility (CSR) has arisen because of certain individuals within a business organisation (THE OBSERVER, 2005; TREBECK, 2005). We represent this blurring between the sectors in Figure 1 and suggest that it precludes the assumption of clear boundaries between the three sectors, yet also necessitates the need for greater conceptual clarity. In order to do this we explore the social economy, social enterprise and social entrepreneurship below before considering how they impact on the regional development of social capital in the next section.

$<$ Insert FIGURE 1 here>

\subsection{SOCIAL ECONOMY}

According to AMIN et al (2003), the term social economy itself dates back to the early nineteenth century, if not before, although its usage in the English-speaking world 
has been a relatively recent phenomena. Thus it has rarely featured in academic debates before the 1990s when it was referred to as the 'third', 'voluntary' and / or 'not-forprofit' sector(s) (AMIN et al., 2002; DART, 2004; HUDSON, 2005). Broadly speaking the social economy can be considered as economic activity performed by organisations that are neither for-profit nor state run organisations and are therefore within the 'Third Sector' (ANHEIER and BEN-NER, 1997; AMIN et al., 2003; ARTHUR et al., 2003; WILLIAMS et al., 2003; HUDSON, 2005; SEAM, 2005). However, the social economy is distinct from both the household and informal economies - also part of the Third Sector - because it consists of formal structures and institutions (see Figure 1).

Although they recognise earlier charitable and voluntary organisations, MOULAERT and AILENEI (2005) also claim that the social economy has largely nineteenth century origins, especially in relation to concerns about inequality. They argue that there were country-specific forms with France developing an 'associative' variant derived from notions of political liberty, whilst English versions were more closely oriented around communities (MOULAERT and AILENEI, 2005; see also LINDSAY and HEMS, 2004). Furthermore MOULAERT and AILENEI align the historical expansion and contraction of the social economy with recurrent capitalist crises and the popular, spontaneous reactions to the threat and effects of liberalism that KARL POLANYI (1944[2001]) recounts in The Great Transformation. It has been suggested that POLANYI's (1957) conceptualisation of exchange based on reciprocity, redistribution and markets neatly maps onto the three-way distinction between the social economy, government provision and the private sector respectively (see LAVILLE and NYSSENS, 2001; LAVILLE, 2003; WILLIAMS et al., 2003). 
The importance of reciprocity as a characteristic of the social economy is evident in the stress laid on non-profit, not-for-profit and voluntary principles, which contrasts with the more recent definition of social enterprises. Non-profits can be defined as organisations that are required to re-invest any profits in the organisation and its activities, whereas not-for-profits may distribute profits between members or stakeholders (MOULAERT and AILENEI, 2005; see also ARTHUR et al., 2003; JONES and KEOGH, 2006). It is also possible to distinguish between non-profits and not-forprofits by arguing that the former are meant to serve public (e.g. national) or social (e.g. local) interests whilst the latter serve the common interest of their members; they can also serve the public and social interest, but are not required to do so (see LINDSAY and HEMS, 2004). ${ }^{\text {ii }}$ Furthermore, voluntary organisations (e.g. charities) can represent a subset of the non-profit sector marked by a distinction between non-governmental organisations (NGOs) and community organisations (MOULAERT and AILENEI, 2005), both of which promote civic society and social cohesion through requirements for 'public benefit'.

\subsection{SOCIAL ENTERPRISE}

Discussions of the social economy often entail a conceptual slippage between the broad concerns of the various organisational forms like charities, voluntary associations and cooperatives that constitute the broader social economy and the specific, relatively new social enterprise model (e.g. HM TREASURY, 1999; SCOTTISH EXECUTIVE, 2003; see HUDSON, 2005). There is also considerable slippage between social enterprise 
and social entrepreneurship with some authors using the terms interchangeably to refer to a set of specific organisational practices (e.g. HARDING, 2004; see also NICHOLLS, 2006). To provide clarity, it is useful to consider social enterprise as representing a "new dynamic within the third sector" and it is therefore only one element in the broader Third Sector (LAVILLE and NYSSENS, 2001, p.624).

The emphasis in recent debates on 'entrepreneurialism' or 'enterprise' can be seen as particular to social enterprise, and especially the activity of social enterprise. As a fairly recent concept, social enterprise encapsulates both a specific form of social economy organisation and, more importantly, a specific form of activity. It is characterised by a business orientation and innovative approach focused on the delivery of social benefits through trading to ensure the financial sustainability of the organisations concerned (BUDD, 2003; ARTHUR et al., 2004). This conceptualisation makes social enterprise distinct from the common definition used by the DTI, which covers an array of different organisations with distinct and sometimes disparate objectives (e.g. charity and workers co-operative):

"A social enterprise is a business with primarily social objectives whose surpluses are principally reinvested for that purpose in the business or in the community, rather than being driven by the need to maximise profit for shareholders and owners" (DTI, 2002, p.8).

Although social enterprise involves a social objective, the definition of such objectives is itself complicated by the different weight given to organisational forms, as well as the 
emphasis placed on market models of trading activity (DART, 2004). For example, worker cooperatives might be excluded from the UK government definition of social enterprise because their social goal is collective ownership, which has been implicitly side-lined by government policies focused on 'stakeholding' (ARTHUR et al., 2004). ${ }^{\text {iii }}$ Therefore it is more useful to argue that social enterprise concerns the pursuit of particular activities rather than representing certain social forms (e.g. cooperatives, democratically-run organisations) with the aim of producing collective benefits (LAVILLE and NYSSENS, 2001).

Thus the main defining characteristic distinguishing social enterprise from the broader social economy is that social enterprise involves the derivation of a significant proportion - between 25 and 50 percent - of organisational income from trading activities (OECD, 1999; DTI, 2002; IFF RESEARCH, 2005; THE OBSERVER, 2005). Furthermore, it has been suggested that social enterprise represents a particular point in the life cycle of social economy organisations; i.e. the point at which they achieve financial sustainability (JOHNSON, 2000; ARTHUR et al., 2004; EIKENBERRY and KLUVER, 2004). This conceptual definition concentrates on the 'activity' rather than 'organisation' of social enterprise because it relates to the extent to which trading (i.e. means) dominates an organisation (NICHOLLS, 2006). Social enterprise can therefore be considered as trading for a social purpose, rather than as a distinct Third Sector organisation with certain characteristics distinct from the reciprocity and mutualism inherent in the social economy (DART, 2004; HAUGH and TRACEY, 2004; HAUGH, 2005a). 


\subsection{SOCIAL ENTREPRENEURSHIP}

Whereas the recent interest in the social economy focuses on organisational forms and for social enterprise on specific activities (i.e. trading), the recent and continuing popularity of social entrepreneurship concentrates on individual motivation and leadership (see LEADBEATER, 1997; THOMPSON et al., 2000; CONE et al., 2003; BORNSTEIN, 2005; SEAM, 2005; JONES and KEOGH, 2006). Consequently all three concepts discussed here constitute an element of the Third Sector rather than representing its defining features (see also PEARCE, 2003). The individual basis of social entrepreneurship is evident in the definitions of MAIR and MARTI (2006) and DEES (2001), which both cut across different typologies and tackle the issue of whether individuals or organisations can engage in social entrepreneurship. However, there is still considerable conceptual slippage between social enterprise and social entrepreneurship in many such definitions (GRENIER, 2002; HOCKERTS, 2006; PEREDO and McLEAN, 2006). We define social entrepreneurship at the individual level because of our argument that the organisational and activity bases of the Third Sector can be represented by the social economy and social enterprise respectively.

We think it is important to define social entrepreneurship in a limited fashion because of the problems evident in 'outcome-based' definitions. Here the conceptualisation of social entrepreneurship can appear self-defining through the naturalisation of certain characteristics as entrepreneurial because they have achieved specific goals (i.e. 'success'). One example of this tendency is represented by BRINCKERHOFF's (2000, p.1) claim that social entrepreneurs are "people who take risk 
on behalf of the people their organization serves" and that "[s]ocial entrepreneurship is one of the essential characteristics of successful not-for-profits". Thus risk and success are presented as two-sides of the same terminology in that without risk there would be no 'success' and without 'success' there would be no need for risk-taking. As such this may simply reflect the introduction of market-driven agendas into the Third Sector in pursuit of self-sufficiency resulting from declining public and private funds (HOCKERTS, 2006). Furthermore, it is important to avoid definitions that are based on the idea that social entrepreneurship refers to the establishment of social enterprises (HAUGH, 2005b; MAIR and MARTI, 2006).

In discussing social entrepreneurship at this individual level we can identify the importance of motivation and leadership. In his now famous definition, DEES (2001, p.2) describes entrepreneurs as people who "mobilize the resources of others to achieve their entrepreneurial objectives". Consequently, social entrepreneurs can be defined as people who act as "change agent[s] in the social sector" through the adoption of a mission, pursuit of new opportunities to achieve that mission, continual "innovation, adaptation and learning", avoidance of limits on current resources, and concern with accountability to clients and community (DEES 2001, p.4). In a similar vein, BORNSTEIN (2005, p.1) writes about social entrepreneurs as "people with new ideas to address major problems who are relentless in the pursuit of their visions". The 'vision' is a crucial aspect of social entrepreneurship, but also for entrepreneurship more generally (see also MORT et al., 2003), consisting of imagination and evangelism, where the former provides the motivation to pursue the latter. Thus the willingness to chart new paths and bring others along with you is based on a set of guiding principles. In some ways this is reminiscent of 
the idea of the 'public entrepreneur' (WADDOCK et al., 1991) or the 'social' or 'civic' entrepreneur (HOCKERTS, 2006), which means that it does not necessarily involve the strategies or activities that characterise the social economy and social enterprise.

\section{THE THIRD SECTOR AND THE REGIONAL DEVELOPMENT OF SOCIAL CAPITAL}

Having briefly summarised the differences between the concepts of the social economy, social enterprise and social entrepreneurship, we now turn to their role in regional development. The Third Sector is linked to regional development in relation to the pursuit of 'sustainable' forms of economic activity (e.g. trading) as well as the creation and development of social capital and broader socio-economic outcomes (see PEARCE, 2003; FLOCKHART, 2005; EVANS and SYRETT, 2007; JONES et al., 2007; see FYFE, 2005 for critical view). Implicit in this view is that certain forms of economic and social activity are sustainable (e.g. markets-driven economic growth) which differs from 'strong' arguments on sustainability (CHATTERTON, 2002). In contrast, sustainability more closely resembles the triple or quadruple bottom line that blends economic, social, ecological and community concerns (ELKINGTON, 2004; REID and GRIFFITH, 2006). Consequently we concentrate on the regional development of social capital in order to consider the implications of policy agendas and initiatives undertaken to encourage, promote and support the Third Sector and their socio-economic impact (AMIN et al., 2002; PEARCE, 2003; AMIN, 2005; HAUGH, 2005a, 2005b; WALLACE, 2005). 
Defining social capital would take another critical survey in itself so we draw on a number of existing reviews of the concept by the likes of WOOLCOCK (1998), FINE (2001), ONS (2001), JOHNSTON and PERCY-SMITH (2003), QUIBRIA (2003), and WESTLUND and BOLTON (2003). The first thing to note is that social capital, despite its meta-theoretical claims, is a diverse concept that cuts across disciplines and has been strongly criticised (e.g. FINE, 2001) despite its popularity in academic and especially policy circles. According to WOOLCOCK (1998) it was first identified by Jane Jacobs and Pierre Bourdieu and later developed by James Coleman, Ronald Burt and Robert Putnam. It can be "generally defined as the information, trust, and norms of reciprocity inhering in one's social networks" (WOOLCOCK, 1998, p.153; also p.189) and conceived as both individual (Bourdieu) and community (Putnam) based as well as functional (Coleman) and consequentialist (see QUIBRIA, 2003).

Like WOOLCOCK (1998, p.168), we differentiate between four types of social capital that all relate to regional development including: (1) norms (e.g. 'bonds' or intracommunity ties), (2) networks (e.g. 'binding' or extra-community ties), (3) links (e.g. 'diversity' or the difference between communities) and (4) holders (e.g. 'bridge-builder' or change agents). These four types of social capital not only relate to the Third Sector in distinct ways, as summarised in Table 1 below, but they also entail geographical specificity in their relationship to particular places and scales; i.e. their context (see PORTES, 1998; WOOLCOCK, 1998). For example, norms can be seen as both a broad scale phenomena covering the whole Third Sector (e.g. mutualism, voluntarism etc.), as well as specific to the Third Sector in distinct places (e.g. local communities). Networks can also be conceptualised in these terms in that they connect different sectors (e.g. 
private, state and Third) as well as different institutions, organisations and people in and across distinct places and scales. In similar terms, the differences (i.e. diversity) between such social actors can cut across scales, whilst the position of such actors (i.e. holders) is also constituted by place and scale.

Although it is possible to construct a typology of the relationship between the Third Sector and social capital as we have done in Table 1, it is important to note that there is a diversity of possible relationships between the two concepts that cannot be captured in such an ideal type. For example, bonding social capital (e.g. norms) of local communities can help in the development of the social economy in that emerging and existing organisations (e.g. social firms) rely upon existing values, beliefs and attitudes (e.g. voluntarism) that help to foster collective action through the building of trust (see MOULAERT and NUSSBAUMER, 2005; EVANS and SYRETT, 2007). In this sense the varieties of social capital embedded within communities, groups and wider society are necessary for the promotion of the Third Sector, but also, just as crucially, they are actively embedded and promoted in place and across scales by the Third Sector in socioeconomic relationships. It is the latter concern, however, that interests us here because it is more relevant to the focus on regional development in this article.

$<$ Insert TABLE 1 here $>$

\subsection{ORGANISATIONAL SOCIAL CAPITAL}


Some authors have argued that there is a misplaced academic and policy emphasis on the social economy as an "economic circuit in its own right" that is embedded in "the 'local', the 'community' or the "neighbourhood"', especially in relation to the alleviation of social exclusion through employment (AMIN et al., 2003, p.31; see also AMIN, 2005; HUDSON, 2005). In conceptualising the characteristics of the social economy in organisational terms, we argue that the regional development of social capital goes beyond such a focus on the employment and employability of socially disadvantaged groups prevalent in these discourses (CHANAN, 1999). Instead, as WILLIAMS et al (2003) argue, the social economy entails norms of mutualism and independence alongside not-for-profit principles that make the focus on employment and employability problematic because it ties organisations to specific locations that may inhibit socioeconomic development as well as limiting the contribution of the social economy to the development of social capital because it would then also be tied to particular places and scales (AMIN, 2005; HUDSON, 2005). Thus it would be difficult to promote extracommunity network ties or the linking of diverse groups embedded in different places where there is an overwhelming focus on local employability.

However, this does not mean that locality, community and place are irrelevant in the development of social capital. ARTHUR et al (2003) argue that the social economy includes local and 'employee' ownership, local and employee control, mutual values, and local finance, whilst others argue that the social economy concerns the addressing of unmet material and social needs at a local level with an "explicit reference to the ethical values of solidarity and reciprocity" (MOULAERT and AILENEI, 2005, p.2048; also MOULAERT and NUSSBAUMER, 2005). This touches on a crucial aspect of social 
capital, namely the necessary link between social and material resources, which is highlighted in the literature (FORREST and KEARNS, 2001; EVANS and SYRETT, 2007). It is particularly important that the pursuit of social objectives like democratic participation, voluntarism and mutualism through economic activity does not lead to profit "leakage" - i.e. leaving an organisation (LINDSAY and HEMS, 2004, p.276) - and consequently the means (i.e. economic activity) are considered to be as important as the ends (i.e. social objective) (EIKENBERRY and KLUVER, 2004). Thus the development of social capital is inextricably tied to material development and therefore the social economy entails the build up of both tangible and intangible community assets through local regeneration and community empowerment (THOMPSON et al., 2000).

The social economy consists of numerous organisations that embed both social and material resources in particular places and provides access across different scales. This organisational and institutional infrastructure promotes social capital by providing access to both types of resource and in particular through the development of mutualism amongst and between different groups thereby leading to greater 'active participation' and 'stakeholding' in society, not just the local community (JESSOP, 2000; AMIN et al., 2002). However, there is a risk of ossification if such organisational and institutional relationships and networks are over-embedded in particular places; i.e. bonding communities together around certain social and material resources, but limiting access to other resources (EVANS and SYRETT, 2007). Thus there are concerns that the development of only one form of social capital (e.g. bonding) can inhibit change, in that the promotion of strong bonds detracts from developing new relationships, whilst also 
limiting access to resources for individuals who are peripheral group members (MAIR and MARTI, 2006).

The importance of extra-local and extra-organisational linkages is therefore crucial, whilst the ethos of mutualism underpinning the social economy helps to alleviate the possibility of insularity highlighted above. The emphasis on mutual, democratic, and voluntary norms can stimulate the development of these networks and foster linkages that avoid local or organisational boundedness (RYDIN and HOLMAN, 2004). Consequently, certain types of social capital (e.g. bonding) are necessary to promote other types of social capital (e.g. binding) and are embedded in the organisations and institutions particular to different places, but they are not sufficient in themselves. Thus there is a need to question the existence of 'excessive' social capital (QUIBRIA, 2003; BARON, 2004), which the social economy can do by enabling these different groups, communities and actors to connect and interact with one another across different places and scales through a shared ethos. However, the social economy does not fully account for the creation of new networks (i.e. bridges) or the evolving process of forging new relationships and networks that link different and diverse groups, organisations and institutions; it is here that social enterprise plays a crucial role as discussed next.

\subsection{ACTIVITY-BASED SOCIAL CAPITAL}

Social enterprise involves the acquisition of funding through trading and sales, rather than grants or donations (CROSSAN et al., 2004), and as such it is closely related, although still distinct from, the public and private sectors; for example, social enterprise 
can involve both the provision of services through public procurement and market exchanges in the private sector (DTI, 2003; JONES et al., 2007). Social enterprise also relates to capacity, in terms of both organisational capabilities and scope, and consequently it is important to consider how such activity, as process, inheres in and across specific territories. Thus, in relation to social capital, the activity of social enterprise has two major functions in regional development. First is the binding of different groups together in a network, both within specific places such as local communities and, more broadly, at the regional and national scale. Second is the linking of diverse and often disparate normative frameworks (e.g. mutualism and profit-seeking) and structures (e.g. social firms and private companies), which produces new insights and resources through inter-group learning. Again this entails territorial embedding because of the linkages forged between regions, or even across scales, that lead to the development of social capital.

Social enterprise is able to bridge diverse groups and therefore assist in the development of social capital through the process of binding actors together, although the lack of an existing organisational or institutional basis of relationships may prove detrimental to this process; e.g. by limiting the social as well as economic resources available for activities (HUDSON, 2005). Social enterprise provides the means through which the process of bridging can occur because it necessitates activity across a number of different spheres (e.g. economic, social, political) incorporating the economic concerns of trading for income with the pursuit of a social purpose, all undertaken with the assumption of democratic accountability to a specific constituency or community (PEARCE, 2003). Such processes entail a shift in emphasis from emergent and informal 
associations that bond groups together, as provided by the social economy, to new modes of operation and governance that move beyond the immediate group or territory (EVANS and SYRETT, 2007). Therefore social enterprise can be seen as the process through which actors can embed themselves in a network of relationships that help to promote the successful pursuit of certain objectives; social, ecological, community or otherwise. However, an unfortunate consequence of this pluralism is that the strong bonding ties (i.e. mutualism) characteristic of the social economy as a whole are necessarily weakened thereby reducing the link with a particular territory or place, whilst co-operation may also be threatened by the turn towards market principles; e.g. competition (EIKENBERRY and KLUVER, 2004; EVANS and SYRETT, 2007).

The threat to bonding social capital may also prove beneficial in that it can lead to the development of new approaches or new connections that are not locally bounded. In particular, the emphasis on trading leads to a market focus in activities which encourages the development of new processes that link diverse concerns and incorporates goals and means that were not previously associated, but can still prove beneficial. However, one major concern here is that values may end up recast as the means to an end, rather than the objective themselves. Thus the regional development of social capital may be considered as the means to economic competitiveness, reducing such values to a process (e.g. trading) for reasons that relate more to ideological assumptions than usefulness (FINE, 2001). Therefore the possibility of pursuing emancipatory or empowering activities during place-specific regeneration and development could be replaced by market-based assumptions and norms that preclude certain activities (e.g. co-operation or collective ownership and control). For example, it has been argued that the Community 
Interest Company legal form recently introduced in the UK fails to challenge existing ownership forms, which thereby precludes the adoption of social or cooperative ownership (ARTHUR et al., 2004). Consequently the motivation behind social enterprise is a central concern in regional development, but one that cannot be addressed in the conceptualisation of social enterprise as process.

\subsection{MOTIVATION-BASED SOCIAL CAPITAL}

In turning to social entrepreneurship, it is important to note that the concept cannot be defined in relation to outcomes nor can it simply relate to just a process. Rather it relates to the issue of individual motivation (i.e. agency) as much as the process of institutional transformation inherent in the pursuit of social change. There are a number of 'agency' definitions of social entrepreneurship such as "any person, in any sector, who uses earned income strategies to pursue a social objective" (BOSCHEE and McCLURG, 2003, p.4). However, the assumption that only income-earning strategies are indicative of social entrepreneurialism is problematic. As JOHNSON (2000, p.12) points out, this definition implicitly accedes to the expectations and objectives of a wider capitalist economy, rather than providing the means to pursue alternative economies such as the 'co-operative commonwealth' (JONES and KEOGH, 2006, p.18). Furthermore, the association between income-earning and entrepreneurialism ignores a whole swathe of people involved in a range of activities from corporate social responsibility (CSR) or corporate philanthropy (TREBECK, 2005) through to 'antipreneurs' from the antiglobalisation movement. ${ }^{\text {iv }}$ It is therefore largely a reformist as opposed to radical 
perspective. Consequently, several writers have argued for an understanding of social entrepreneurship that accounts for a range of individual characteristics such as leadership, vision and risk-taking; all of which add extra dimensions to the concept (LEADBEATER, 1997; THOMPSON et al., 2000; DEES, 2001; MORT et al., 2003; MAIR and MARTI, 2006; PEREDO and McLEAN, 2006).

When this 'agency' conceptualisation of social entrepreneurship is wedded to the idea of 'process', it shows how social value is created through the "innovative use and combination of resources to pursue opportunities to catalyse social change and/or address social needs" (MAIR and MARTI, 2006, p.37). In particular, HOCKERTS (2006, p.7-13) outlines three sources of social entrepreneurialism covering activism, self-help and philanthropy, which all impact on social capital development. However, the process of innovation does not necessarily sit well with policy objectives aimed at community empowerment or capacity building because innovation - in Schumpeterian terms - would entail the 'creative destruction' of existing institutions, organisations and communities and their replacement by new ones (see ZAFIROVSKI, 1999). In some ways then this view of social entrepreneurship (e.g. LEADBEATER, 1997) is limited by the assumption that entrepreneurialism implicitly concerns new processes that may unnecessarily break down existing institutional structures, social relationships etc. Thus it is important to embed the notion of individual motivation with that of process in order to avoid the 'destruction' that innovation can mean for the regional development of social capital.

Using the concept of social entrepreneurship outlined above that is oriented around the wedding of agency with process, it is possible to identify the important linking role performed by social entrepreneurs, whether in terms of a person or group, in the 
production of social capital that connects process-agents to diverse social actors drawn from across the three sectors (PURDUE, 2001; GRENIER, 2002). Thus social entrepreneurship involves, on the one hand, collaboration with a diverse and often disparate range of people, groups and organisations, and, on the other hand, the promotion and development of new networks of such divergent interests in the pursuit of specific social goals (JOHNSON, 2000; PEREDO and McLEAN, 2006). However, just as this may prove destructive of existing social capital, it may also preclude challenges to existing interests, necessitating that social entrepreneurship adheres to a 'reformist', as opposed to 'radical', social agenda (JONES and KEOGH, 2006). It also rests on the social entrepreneur developing a specific form of social capital (i.e. bridge-builder), which may entail inadequate accountability and democratic governance.

The development of linking social capital is central to social entrepreneurship because it concerns the capability to juggle the triple or quadruple bottom line necessary for sustainable development. Where greater emphasis is placed on economic sustainability over social and ecological issues this may prove problematic. Consequently, the issue of accountability in social entrepreneurship is vital because it is only through considerations of 'stakeholding' and other forms of 'citizenship' (see TRACEY et al., 2005) that social entrepreneurship gains any legitimacy (MORT et al., 2003; DART, 2004; NICHOLLS, 2006; REID and GRIFFITH, 2006). Thus community empowerment and accountability necessitates a focus on social embeddedness (MAIR and MARTI, 2006), which may be sidelined where there are disparities in power engendered by the implicit ability of individual social entrepreneurs to define the 'good' 
and 'bad' characteristics of society (QUIBRIA, 2003; BARON, 2004) and their capacity to operate across different geographical scales.

\section{THE THIRD SECTOR AND REGIONAL POLICY IN THE UK}

In turning to the implications of the Third Sector for regional policy, it is important to distinguish between policy agendas (i.e. discursive claims) and policy initiatives (i.e. implementation). Although we acknowledge that conceptual clarity is not necessarily possible, or even desirable, ${ }^{\mathrm{v}}$ it is evident that there are numerous conceptual slippages in policy discourse and its application that problematically blur the already hazy distinctions between the private, state and Third sectors (e.g. SCOTTISH EXECUTIVE, 2003; see ARTHUR et al., 2003). Such conceptual fuzziness not only presents a problem in assessing regional policy, it also inherently confuses a number of policy aims and their subsequent implementation. Here we concentrate on UK and Scotland in order to focus the discussion of Third Sector policy and to consider the difference in such policy agendas and their implementation at different scales. As mentioned previously, we have chosen to focus on Scotland for a number of reasons. First, it has suffered from long-term socio-economic uneven development; second, it has a policy agenda distinct from the national and other devolved governments; and finally, the wealth of policy literature on Scotland is greater than for other regions of the UK (see JONES et al., 2007).

\subsection{THIRD SECTOR POLICY AGENDAS}


At the UK level, policy agendas have tended to conflate social enterprise with the social economy and even the broader Third Sector, despite the significant differences that exist between these concepts. Thus policy that initially focused almost exclusively on social enterprise (e.g. DTI, 2002, 2003) has not changed despite the recent establishment of the Office of the Third Sector (OTS) in 2006. This is demonstrated in the similarity between the definitions used in the 2002 DTI social enterprise strategy and 2006 OTS report on the role of the Third Sector in regeneration. The former defines social enterprise as:

“...a business with primarily social objectives whose surpluses are principally reinvested for that purpose in the business or in the community, rather than driven by the need to maximise profit for shareholders and owners" (DTI, 2002, p.8).

The latter defines the Third Sector in a similar vein as:

“...non-governmental organisations which are value-driven and which principally reinvest their surpluses to further social, environmental or cultural objectives" (HM TREASURY and CABINET OFFICE, 2006, p.5).

\footnotetext{
Such inability to differentiate between the different features of the Third Sector leads to a number of problematic assumptions when considering not only how to measure the sector (in essentialist terms, see MOULAERT and NUSSBAUMER, 2005), but also how to 
measure the impact of policy initiatives, especially in relation to regional development and local regeneration.

The definitional shift does not necessarily represent an accidental confusion of concepts since an ECOTEC report commissioned by the DTI had explicitly referred to social enterprise as the 'trading' arm of the Third Sector, or "that part of the social economy which is primarily engaged in trading" (ECOTEC, 2003, p.22). Thus it appears to be a more deliberate discursive attempt to identify certain activities (i.e. trading) with specific qualities (i.e. enterprise and entrepreneurialism) that side-line other possible policy discourses (e.g. 'strong' sustainability - see CHATTERTON, 2002).

There is further evidence of this perspective in regional policy agendas in relation to Scotland; not least because Scottish policy is increasingly aligned with the broader UK agenda (see SCOTTISH EXECUTIVE, 2007b). However, Scottish policy discourse is different in that it makes a clearer distinction between the social economy and social enterprise by stating that social enterprise is part of the social economy (e.g. SCOTTISH EXECUTIVE, 2006). Furthermore, there are separate reviews and strategy documents that differentiate between the two (e.g. SCOTTISH EXECUTIVE, 2003; SCOTTISH EXECUTIVE, 2006) with a change in emphasis from a specific organisational structure to an activity (i.e. entrepreneurial and income earning) over time (SCOTTISH EXECUTIVE, 2007a). In particular, the Scottish policy agenda has been strongly influenced by the threat of lost European development funding in 2007, although such concerns are prevalent throughout the UK as well (AMIN et al, 2003; CROSSAN et al., 2004; FLOCKHART, 2005; WALLACE, 2005; HM TREASURY and CABINET OFFICE, 2006). Thus the focus on social enterprise is driven by concerns with financial 
self-sufficiency, not only for the organisations themselves in terms of grant dependency (JONES et al, 2007), but also for local communities in relation to government funding and the implementation of government policy (e.g. public service reform) through social enterprise (see RIDLEY-DUFF, 2007, p.388). ${ }^{\text {vi }}$

\subsection{THIRD SECTOR POLICY INITIATIVES}

The concern with the financial sustainability of the social economy and local communities also helps to explain the interest in the development of social capital as a resource for community economic development, regeneration and empowerment (see SMALLBONE et al, 2001; SCOTTISH EXECUTIVE, 2003; HM TREASURY and CABINET OFFICE, 2006; OTS, 2006; SCOTTISH EXECUTIVE, 2006; SCOTTISH EXECUTIVE, 2007b). Tying together this policy agenda of "[b]uilding human and social capital ... to strengthen local communities which is essential if there is to be successful regeneration" (HM TREASURY, 1999, p.107) and the various policy initiatives undertaken to ensure its success is the UK Labour government's view that citizenship as constituted by employment participation (SOCIAL JUSTICE COMMISSION, 1994; AMIN et al., 2002; WILLIAMS et al., 2003). Therefore a key aspect of social enterprise policy intervention is "empowering individuals and communities, encouraging the development of work habits and increasing employment diversity" (DTI, 2002, p.21; also see HM TREASURY 1999, pp.107-108).

It is important to take this particular focus on employment participation into account when considering the promotion of social capital in the UK because social 
enterprise policy initiatives directed at community development, regeneration and empowerment are more oriented towards finding market solutions for market failures as opposed to socio-economic ones. For example, early initiatives were directed at 'creating an enabling environment', 'making social enterprises better businesses' and 'establishing the value of social enterprise' (see DTI, 2002), and were implemented through the introduction of new organisational forms (e.g. the Community Interest Company in 2005) and funding institutions (e.g. Community Development Finance in 2003) alongside profile raising initiatives supporting organisations like the Social Enterprise Coalition (DTI, 2003; see also AFFLECK and MELLOR, 2006; RIDLEY-DUFF, 2007). Much of this activity does not directly address the concern with developing social capital or social cohesion in deprived communities (see SMALL BUSINESS SERVICE, 2005b), but rather implicitly assumes that the promotion of market solutions will release an entrepreneurial spirit in these localities.

In Scotland there was a greater emphasis on the broader social economy, rather than a specific focus on social enterprise (e.g. SCOTTISH EXECUTIVE, 2003), although this has changed more recently (e.g. SCOTTISH EXECUTIVE, 2006, 2007a, 2007b). However, the 2004 introduction of Local Social Economy Partnerships (LSEP) can be seen as creating a more bottom-up approach in Scotland (see SCOTTISH EXECUTIVE, 2004, 2006) in comparison to the top-down initiatives favoured by the UK national government such as the voluntary sector Compacts and, particularly, their application in England (FYFE, 2005). There are supposed to be LSEPs in every local authority in Scotland providing the means to co-ordinate cross-sector activities in support of the Third Sector and its role in local development and regeneration (e.g. SEAM 2005). Despite this 
supposedly bottom-up approach, it has been argued that the emphasis on community regeneration has led the Scottish Executive to side-step local government in favour of community partnerships that are less accountable (see COLLINS, 2006). Furthermore, there are concerns about the disparity between how LSEPs operate in and across Scotland (SCOTTISH EXECUTIVE, 2007a) as well as an increasingly evident emphasis on topdown initiatives (see SCOTTISH EXECUTIVE, 2007b).

In terms of direct government investment, this has been driven by a number of different funding schemes, but has been particularly focused on the provision of public services rather than the promotion of social capital. Most notable is the $£ 125$ million Futurebuilders programme established in 2004 as a non-profit company (DTI, 2003; AFFLECK and MELLOR, 2006), which is designed to support the Third Sector in public service delivery. ${ }^{\text {vii }}$ Consequently it contributes to the reworking of governance that follows on from the 'compacts' mentioned above, which themselves entail an agreement by voluntary sector organisations "that public funding is provided on the basis of its contribution to government "policy priorities"” (FYFE, 2005, p.543). viii Thus in Scotland the $£ 18$ million Futurebuilders fund is mainly directed towards 'investment', alongside contributions to 'training' and 'support', with a sizeable proportion of this funding ( $£ 12$ million) set aside for medium and large sized organisations that are already providing services in order to promote "capital investment and to encourage them to operate in a more business-like fashion" (SCOTTISH EXECUTIVE, 2004, p.4). However, the emphasis on growth and expansion has certain implications for local empowerment and participation since it has been argued that larger organisations, oriented more towards 
service delivery, produce "passive forms of citizenship" (FYFE, 2005, p.550), which implies that social capital is neither encouraged nor developed.

As is evident in the discussion above, it is often difficult to identify what impact the implementation of policy has on the promotion of social capital. In the DTI policy vision, for example, social enterprise is seen as a "key factor" in local community development through "empowering individuals and communities" (DTI, 2002, p.21). However, there are a number of barriers to the regional and local development of social capital implicit in the policy initiatives designed to encourage social enterprise (see WILLIAMS et al., 2003). First, communities may lack the necessary material resources that go hand-in-hand with developing social capital in particular localities and communities (EVANS and SYRETT, 2007), whilst a top-down, service delivery model is unlikely to provide the material capital desired by local communities. Second, individuals and communities may lack the wide or strong networks necessary for the expansion of social capital, especially where there is a deficit of embedded values or trust in a particular place and relevant interpersonal and communication skills necessary for developing social capital. Finally, individuals and communities may have to work within specific institutional boundaries (e.g. tax credit, welfare systems) that proscribe certain actions and activities (WILLIAMS et al., 2003, p.156), limiting choice to a set of prescriptive policies rather than those suited to local specificity.

\section{CONCLUSION}


This paper has sought to contribute to the existing debate on the Third Sector by providing an overlapping definition of the social economy, social enterprise and social entrepreneurship that seeks to situate them within the overall Third Sector. As such it has sought to emphasise the importance of regional socio-economic development in reference to social embeddedness and social capital.

We outlined how the social economy is characterised by a combination of both organisational forms and values, whereas social enterprise can be seen as a particular type of activity - namely the earning of income through trading in pursuit of a social objective - representing a drive towards financial self-sufficiency. Although this is a more restrictive definition than others may use, it is meant to distinguish between the particularities of social enterprise and other constituent forms of social economy organisation and activity that embody different values (e.g. worker co-operatives). The final category, social entrepreneurship, is also broadly used and therefore in need of greater conceptual clarity. Here we focused on the individual level and especially the importance of combining motivation and vision in order to bring together a diverse and often divergent set of interests in the pursuit of the entrepreneur's goal.

After the explication of the three core concepts we considered how the Third Sector can contribute to the regional development of social capital; a major policy agenda. In particular we argue that the social economy can be seen as encouraging two types of social capital: bonding - in the form of norms and values - and binding - in the form of mutual and democratic processes. In turn, social enterprise encourages both binding and linking social capital in that it links together different objectives derived from social and market principles. Finally, social entrepreneurship promotes linking and 
motivational social capital through the encouragement of particular visions of social change that cut across organisational and institutional boundaries. Throughout we have stressed that such development is both place specific and inter-dependent in that one form of social capital is not enough to ensure regional socio-economic development nor is the encouragement of social capital always necessarily beneficial. Instead it is important to consider how the encouragement of different types of social capital can lead to problematic outcomes.

In the final section we have considered the relationship between UK and Scottish (i.e. regional) Third Sector policy agendas and initiatives, especially in relation to the regional development of social capital. Here we have identified a shift in policy discourse from treating social enterprise as a distinct category in the Third Sector to the constitutive feature of the Third Sector. We then showed how the implementation of policy initiatives has been based on a specific agenda of public services reform, which not only fails to encourage social capital but also side-lines a number of core features of the Third Sector such as mutualism, democratic control and accountability. In particular, policy discourse and implementation has failed to consider the relationship between material and social capital in regional development and local regeneration. Overall we would argue that it is vital for regional policy to encourage and generate both financial and social capital because of the possible loss of both that either would cause when developed alone (see CALLISON, 2003).

\section{ACKNOWLEDGEMENTS}


Earlier versions of this paper were presented at the 2005 Regional Studies Association annual conference as well as the 2007 CPPR Seminar Series. This article has benefited from discussions at these events as well as the specific comments of Andrew Cumbers, Katherine Trebeck and the anonymous referees on earlier drafts. Usual disclaimers apply.

\section{REFERENCES}

ADAMS, J., ROBINSON, P. and VIGOR, A. (2003) A new regional policy for the UK. IPPR, London.

AFFLECK, A. and MELLOR, M. (2006) Community Development Finance: A NeoMarket Solution to Social Exclusion? Journal of Social Policy 35(2), 303-319.

AMIN, A. (2005) Local community on trial, Economy and Society 34(4), 612-633.

AMIN, A., CAMERON, A. and HUDSON, R. (2002) Placing the Social Economy. Routledge, London.

- (2003) The Alterity of the Social Economy, in LEYSHON, A., LEE, R. and WILLIAMS, C. (eds) Alternative Economic Spaces. SAGE Publications, London.

ANHEIER, H. and BEN-NER, A. (1997) Shifting Boundaries: Long-term changes in the size of the for-profit, nonprofit, cooperative and government sectors. Annals of Public and Cooperative Economics 68(3), 335-353.

ARTHUR, L., SCOTT CATO, M., KEENOY, T. and SMITH, R. (2003) Developing an Operational Deifinition of the Social Economy. Journal of Cooperative Studies 36(3). 
ARTHUR, L., KEENOY, T., SMITH, R., SCOTT CATO, M. and ANTHONY, P. (2004) People versus pounds: the prospects for radicalism in the UK social economy. Crises conference on Innovation and Social Transformation, Montreal University, 11-12 November.

BARON, S. (2004) Social Capital in British Politics and Policy Making, in FRANKLIN, J. (ed.) Politics, Trust and Networks: Social Capital in Critical Perspective. Families \& Social Capital ESRC Research Group Working Paper no.7, South Bank University.

BORNSTEIN, D. (2005) How to Change the World: Social Entrepreneurs and the Power of New Ideas. Penguin Books, New Delhi.

BOSCHEE, J. and McCLURG, J. (2003) Towards a Better Understanding of Social Entrepreneurship: Some Importance Distinctions. $\underline{\text { http://www.se- }}$ alliance.org/better_understanding.pdf. Accessed 24 May 2006.

BRINCKERHOFF, P. (2000) Social Entrepreneurship. John Wiley \& Sons, New York. BRINDLE, D. (2006) Marking out the territory. The Guardian (20 September 2006), Society Section.

BUDD, L. (2003) Can Social Enterprise Succeed in Building the Regional Agenda? Regions 243(1), 7-11.

CALLISON, S. (2003) 'All You Need is Love?' Assessing Time Banks as a Tool for Sustainable Economic Development. Local Economy 18, 264-267.

CHANAN, G. (1999) Employment policy and the Social Economy: promise and misconceptions. Local Economy 13(4), 361-368. 
CHATTERTON, P. (2002) 'Be Realistic: Demand the Impossible'. Moving Towards 'Strong' Sustainable Development in an Old Industrial Region. Regional Studies 36(5), $552-561$

COLLINS, C. (2006) 'The Scottish Executive is open for business': The New Regeneration Statement, The Royal Bank of Scotland and the Community Voices Network. Variant 26: 10-13.

CONE, C., FELDMAN, M. A. and Da SILVA, A. (2003) Causes and Effects. Harvard Business Review 81(7), 95-103.

CROSSAN, D., BELL, J. and IBBOTSON, P. (2004) Towards a Classification Framework for Social Enterprises. Third Sector Research Programme, University of Ulster.

DART, R. (2004) The Legitimacy of Social Enterprise. Nonprofit Management and Leadership 14(4), 411-424.

DEES, J. G. (2001) The Meaning of 'Social Entrepreneurship'. CASE, Duke University. http://www.fuqua.duke.edu/centers/case/documents/dees_SE.pdf, Accessed 13 July 2006. DEVINE-WRIGHT, P., FLEMING, P. and CHADWICK, H. (2001) Socio-psychological perspective. Impact Assessment and Project Appraisal 19(2), 161-167.

DTI (2002) Social Enterprise: a strategy for success. Department of Trade and Industry, London.

- (2003) Social Enterprise: A progress report on Social Enterprise. Department of Trade and Industry, London.

EC (2000) Commission Discussion Paper - The Commission and Non-governmental Organisations: Building a Stronger Partnership. European Commission, Brussels. 
ECOTEC (2003) Guidance on Mapping Social Enterprise: Final Report to the DTI Social Enterprise Unit. Department of Trade and Industry, London.

EIKENBERRY, A. and KLUVER, J. (2004) The Marketization of the Nonprofit Sector: Civil Society at Risk? Public Administration Review 64(2), 132-140.

ELKINGTON, J. (2004) Enter the Triple Bottom Line, in HENRIQUES, A. and RICHARDSON, J. (eds) The Triple Bottom Line. Earthscan, London.

EVANS, M. and SYRETT, S. (2007) Generating Social Capital? The Social Economy and Local Economic Development. European Urban and Regional Studies 14(1), 55-74.

FINE, B. (2001) Social Capital versus Social Theory. Routledge, London.

FLOCKHART, A. (2005) Raising the profile of social enterprises. Social Enterprise Journal 1(1), 29-42.

FORREST, R. and KEARNS, A. (2001) Social Cohesion, Social Capital and the Neighbourhood. Urban Studies 38(12), 2125-2143.

FYFE, N. (2005) Making Space for "Neo-communitarianism"? The Third Sector, State and Civil Society in the UK. Antipode 37(3), 536-557.

GRENIER, P. (2002) The Function of Social Entrepreneurship in the UK. ISTR Conference, Cape Town, July 2002.

HARDING, R. (2004) Social Enterprise: The New Economic Engine. Business Strategy Review 15(4), 39-43.

HARDING, R. and COWLING, M. (2004) GEM: Social Entrepreneurship Monitor United Kingdom 2004. London Business School, London.

HAUGH, H. (2005a) The role of social enterprise in regional development. International Journal of Entrepreneurship and Small Business 2(4), 346-357. 
- (2005b) A research agenda for social entrepreneurship. Social Enterprise Journal $1(1), 1-12$.

HAUGH, H. and TRACEY, P. (2004) The Role of Social Enterprise in Regional Development. Social Enterprise and Regional Development Conference, Cambridge-MIT Institute, University of Cambridge.

HM TREASURY (1999) Enterprise and Social Exclusion: National Strategy for Neighbourhood Renewal. HM Treasury, London.

HM TREASURY and CABINET OFFICE (2006) The future role of the third sector in social and economic regeneration: interim report. HMSO, London.

HOCKERTS, K. (2006) Entrepreneurial Opportunity in Social Purpose Business Ventures, in MAIR, J., ROBERTSON, J. and HOCKERTS, K. (eds) Social Entrepreneurship. Palgrave Macmillan, London.

HUDSON, R. (2005) The Social Economy Beyond the Local? Developmental Possibilities, Problems and Policy Considerations. Urbanistica, Forthcoming. http://eprints.dur.ac.uk/archive/00000049/. Accessed 13 July 2006.

IFF RESEARCH LTD (2005) A Survey of Social Enterprise Across the UK. Small Business Service, London.

JESSOP, B. (2000) Globalisation, entrepreneurial cities and the social economy, in HAMEL, P., LUSTIGER-THALER, M. and MAYER, M. (eds) Urban Movements in a Global Environment. Routledge, London.

JOHNSON, S. (2000) Literature Review of Social Entrepreneurship. Canadian Centre for Social Entrepreneurship, University of Alberta. 
JOHNSTON, G. and PERCY-SMITH, J. (2003) In search of social capital. Politics and Policy 31(3), 321-334.

JONES, D. and KEOGH, W. (2006) Social enterprise: A case of terminological ambiguity and complexity. Social Enterprise Journal 2(1), 11-26.

JONES, D., KEOGH, W. and O'LEARY, H. (2007) Developing the Social Economy: critical review of the literature. Communities Scotland, Edinburgh.

LAVILLE, J-L. (2003) A New European Socioeconomic Perspective. Review of Social Economy 61(3), 389-405.

LAVILLE, J.-L. and NYSSENS, M. (2001) The Social Enterprise: Towards a Theoretical Socio-economic Approach, in BORZAGA, C. and DEFOURNY, J. (eds) The Emergence of Social Enterprise. Routledge, London.

LEADBEATER, C. (1997) The rise of the social entrepreneur. Demos, London.

LINDSAY, G. and HEMS, L. (2004) Societes Cooperatives d'Interet Collectif: The Arrival of Social Enterprise Within the French Social Economy. Voluntas: International Journal of Voluntary and Nonprofit Organizations 15(3), 265-286.

MAIR, J. and MARTI, I. (2006) Social entrepreneurship research: A source of explanation, prediction, and delight. Journal of World Business 41, 36-44.

MATHIASON, N. (2005) Social Enterprise: Business phenomenon of the century. The Guardian, 20 November 2005.

McGREGOR, A., GLASS, A. and CLARK, S. (2003) ReValuing the Social Economy. CEiS, University of Glasgow.

MORIN, M., SIMMONDS, D. and SOMERVILLE, W. (2004) Social Enterprise: Mainstreamed from the Margins? Local Economy 19(1), 69-84. 
MORT, G., WEERAWARDENA, J. and CARNEGIE, K. (2003) Social entrepreneurship: Towards conceptualisation. International Journal of Nonprofit and Voluntary Sector Marketing 8(1), 76-88.

MOULAERT, F. and AILENEI, O. (2005) Social Economy, Third Sector and Solidarity Relations: A Conceptual Synthesis from History to Present. Urban Studies 42(11), 20372053.

MOULAERT, F. and NUSSBAUMER, J. (2005) Defining the Social Economy and its Governance at the Neighbourhood Level: A Methodological Reflection. Urban Studies 42(11), 2071-2088.

NICHOLLS, A. (2006) Playing the field: a new approach to the meaning of social entrepreneurship. Social Enterprise Journal 2(1).

OECD (1999) Social Enterprises. Organisation for Economic Co-operation and Development, Paris.

ONS (2001) Social Capital: A review of the literature. Office of National Statistics, London.

OTS (2006) Social enterprise action plan: Scaling new heights. Office of the Third Sector, London.

- (2007) Consultation on the Community Assets Fund. Office of the Third Sector, London.

PATON, R. (2003) Managing and Measuring Social Enterprises. SAGE Publications, London.

PEARCE, J. (2003) Social Enterprise in Anytown. Calouste Gulbenkian Foundation, London. 
PEREDO, A. and McLEAN, M. (2006) Social entrepreneurship: A critical review of the concept. Journal of World Business 41, 56-65.

POLANYI, K. (1957) The economy as instituted process, in POLANYI, K., ARENSBERG, C. and PEARSON, H. (Eds) Trade and Market in the Early Empires, Free Press and Falcon's Wing Press, Illinois.

— (2001) [1944] The Great Transformation. Beacon Press, Boston.

PORTES, A. (1998) Social Capital: Its Origins and Applications in Modern Sociology. Annual Review of Sociology 24(1), 1-24.

PURDUE, D. (2001) Neighbourhood Governance: Leadership, Trust and Social Capital. Urban Studies 38(12), 2211-2224.

QUIBRIA, M. (2003) The Puzzle of Social Capital: A Critical Review. Asian Development Review 20(2), 19-39.

REID, K. and GRIFFITH, J. (2006) Social enterprise mythology: critiqueing some assumptions. Social Enterprise Journal 2(1), 1-10.

RIDLEY-DUFF, R. (2007) Communitarian Perspectives on Social Enterprise. Corporate Governance 15(2), 382-392.

RYDIN, Y. and HOLMAN, N. (2004) Re-evaluating the Contribution of Social Capital in Achieving Sustainable Development. Local Environment 9(2), 117-133.

SCOTTISH EXECUTIVE (2003) A Review of the Scottish Executive's Policies to Promote the Social Economy. Scottish Executive, Edinburgh.

- (2004) Futurebuilders Scotland: Investing in the Social Economy. Scottish Executive, Edinburgh. 
- (2006) A social enterprise strategy for Scotland: a consultation. Scottish Executive, Edinburgh.

- (2007a) A social enterprise strategy for Scotland: Consultation response. Scottish Executive, Edinburgh.

— (2007b) Better business: A strategy and action plan for social enterprise in Scotland. Scottish Executive, Edinburgh.

SEAM (2005) The Social Economy in Midlothian: A Framework for Development. Social Enterprise Alliance for Midlothian, Dalkeith.

SEELOS, C. and MAIR, J. (2005) Sustainable Development: How Social Entrepreneurs Make It Happen. Working Paper No.611, IESE Business School - University of Navarra. SMALLBONE, D., EVANS, M., EKANEM, I. and BUTTERS, S. (2001) Researching Social Enterprise. Small Business Service, London.

SMALL BUSINESS SERVICE (2005) Social enterprise: emerging priorities, Working Group Meeting with Alun Michael. Small Business Service, London.

SOCIAL ENTERPRISE COALITION (2003) There's more to business than you think: A guide to social enterprise. The Social Enterprise Coalition, London.

SOCIAL JUSTICE COMMISSION (1994) Social Justice: Strategies for National Renewal. Vintage, London.

THE OBSERVER (2005) Social Enterprise: Supplement. The Observer, 20 November 2005.

THOMPSON, J., ALVY, G. and LEES, A. (2000) Social entrepreneurship - a new look at the people and the potential. Management Decision 38(5), 328-338. 
TRACEY, P., PHILLIPS, N. and HAUGH, H. (2005) Beyond Philanthropy: Community Enterprise as a Basis for Corporate Citizenship. Journal of Business Ethics 58, 327-344. TREBECK, K. (2005) Democratisation Through Corporate Social Responsibility? The Case of Miners and Indigenous Australians. The Centre for Aboriginal Economic Policy Research (CAEPR), Australia National University. Unpublished PhD Thesis.

WADDOCK, S. and POST, J. (1991) Social Entrepreneurs and Catalytic Change. Public Administration Review 51(5), 393-401.

WALLACE, B. (2005) Exploring the meanings(s) of sustainability for community based social entrepreneurs. Social Enterprise Journal 1(1), 78-89.

WESTLUND, H. and BOLTON, R. (2003) Local Social Capital and Entrepreneurship. Small Business Economics 21, 77-113.

WILliAMS, C., ALDRIDGE, T. and TOOKE, J. (2003) Alternative Exchange Spaces, in LEYSHON, A. LEE, R. and WILLIAMS, C. (eds) Alternative Economic Spaces. SAGE Publications, London.

WOOLCOCK, M. (1998) Social capital and economic development: Toward a theoretical synthesis and policy framework. Theory and Society 27, 151-208.

ZAFIROVSKI, M. (1999) Probing into the social layers of entrepreneurship: outlines of the sociology of enterprise. Entrepreneurship and Regional Development 11, 351-371. 
FIGURE 1: THE PRIVATE, PUBLIC AND THIRD SECTORS

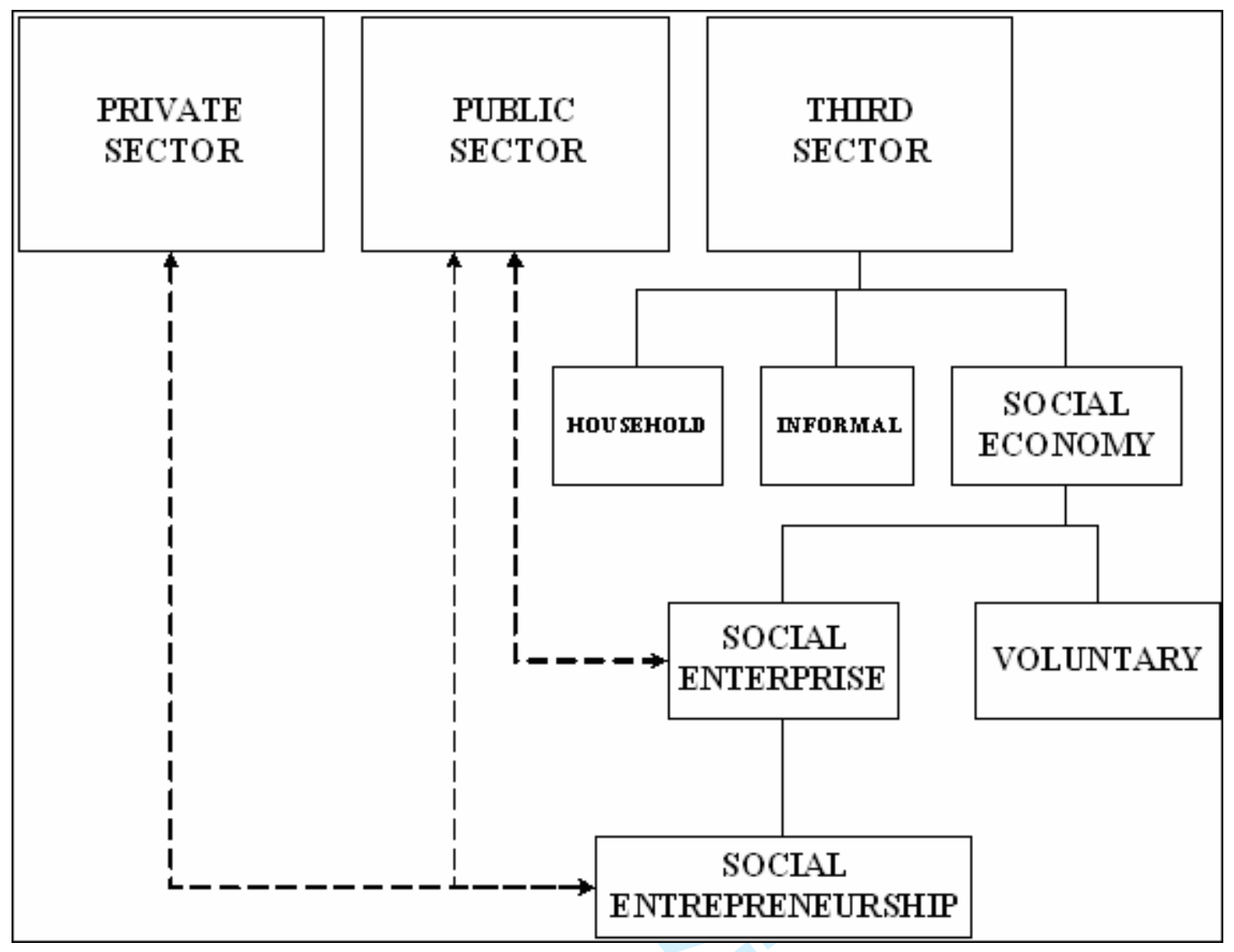


TABLE 1: RELEVANCE OF THE THIRD SECTOR TO THE REGIONAL DEVELOPMENT OF SOCIAL CAPITAL

\begin{tabular}{lccc}
\hline SOCIAL CAPITAL & Social & Social & Social \\
& Economy & Enterprise & Entrepreneurship \\
\hline Structure (bridge) & $\mathrm{X}$ & - & - \\
Process (bridging) & $\mathrm{X}$ & $\mathrm{X}$ & - \\
Diversity (bridged) & - & $\mathrm{X}$ & $\mathrm{X}$ \\
Holder (bridge-builder) & - & - & $\mathrm{X}$ \\
\hline
\end{tabular}

1

2

4

5

6

10

11

12

13

14

15

16

17

18

19

20

21

22

23

24

25

26

27

28

29

30

31

32

33

34

35

36

37

38

39

40

41

42

43

44

45

46

47

48

49

50

51

52

53

54

55

56

57

58

59

60 


\footnotetext{
${ }^{\text {i }}$ REID and GRIFFITH (2006: 2) even talk about a 'quadruple' bottom line consisting of economic, social, ecological and community empowerment goals.

ii MOULAERT and AILENEI (2005) suggest that the English-speaking literature has largely ignored the role of not-for-profit organisations like producer or consumer cooperatives, which represent more continental European organisational types

iii Some argue that government policies such as the new Community Interest Company legal form are actually driven by enabling access to finance rather than promoting stakeholder models of governance (LINDSAY and HEMS, 2004, p.283).

${ }^{\text {iv }}$ http://adbusters.org/metas/politico/antipreneur/forum/ (accessed June 2006).

${ }^{v}$ One of the anonymous referees emphasised the point that the diversity of concepts "cannot and should not be eradicated".

${ }^{v i}$ More recently the UK government has sought to downplay the role of the Third Sector in public services reform (see BRINDLE, 2006).

vii http://www.futurebuilders-england.org.uk/content/QuestionsandAnswers1/-article_37_25.aspx?iid=78
} (accessed April 2007).

viii The UK government announced a new scheme in December 2006 called the Community Assets Fund. This established a $£ 30$ million fund to promote the transfer of local authority assets to Third Sector organisations in order to "increase the community ownership or management of assets, to enable community organisations to be successful and independent in the way they respond to local needs, strengthen cohesion and promote wellbeing" (OTS, 2007, p.2). 